supervision be too evident." Mr. Githens' failure to distinguish clearly between current and desirable practice is evident in the following additional illustrations: (3) $\mathrm{He}$ states that "all available walls should be lined with books." (4) $\mathrm{He}$ asserts that "daylight is preferred in a library." All of these recommendations are debatable, and whatever happens to be the most frequent current practice may actually be the least desirable practice.

Some readers may feel that Mr. Githens' treatment of library buildings trends is perhaps a little too noncommittal compared to the way some other chapters are handled. There is quite a contrast between $\mathrm{Mr}$. Githens' rather neutral account of certain current trends in library building design and such emotionally charged condemnations or endorsements as the following taken from other chapters. With reference to department store design: "It is unfortunate that we have borrowed, as an environment for this comparatively recent retail process, the academic architectural styles" (Kenneth C. Welch); or with reference to bridges and highway architecture: "We all must move with the spirit of our times, and to an architect the only genuinely satisfying work is that which expresses the current mood; even those men who are regarded by the radical fringe as hopeless conservatives do work which 25 years ago would have been considered as extraordinarily advanced even by the radical fringe of that day. Fortunately the modern idiom with its emphasis on clean lines, on structure, and on the elimination of ornament is almost ideal as a treatment for engineering works" (Aymar Embury II).

Libraries receive additional attention in the chapters on college and universities and on daytime schools. Many observations applicable to libraries can also be found in the chapters on office building, factory buildings, hotels, department stores, acoustics, mechanical equipment, non-bearing walls, columns and piers, elements of the modern interior, color in architecture, and, last but not least, the chapter on the process of architectural planning, which emphasizes the importance of a program statement listing the requirements and purposes of any building to be designed.

The set can be highly recommended as a reference and working tool for all academic libraries. From the point of view of reference librarians, the usefulness of the publication has been greatly enhanced by the inclusion of 2 detailed indexes covering 102 pages, one arranged by subjects and one by architectural works. In addition, each chapter contains carefully selected bibliographies.Robert H. Muller, Southern Illinois University Libraries.

\section{California Librarians}

The California Librarian Education Survey, a report to President Robert G. Sproul, University of California. By Robert D. Leigh. New York, Columbia University, 1952. I IO p.

A California librarian would find it difficult indeed to take a detached view of a report which goes to the heart of the vital problem of the training and recruitment of librarians in California. To Dr. Robert D. Leigh was assigned the task of conducting a survey "to determine if there is need for an additional school of librarianship in California, and if so, whether 'that need may be met best by establishing such a school on the University's Los Angeles campus.'" The assignment was made on the basis of representations made to the Regents of the University that not enough librarians are graduated from the existing schools of librarianship at the University of California's Berkeley campus and the University of Southern California to meet the needs of a state which has doubled its population in ten years.

The resulting report not only summarizes Dr. Leigh's findings and recommendations with regard to an additional library school under the auspices of the University of California, but also includes a number of thoughtful and provocative suggestions for the development of librarian training in the state, which are concomitant conclusions gathered from the facts assembled by the survey.

Dr. Leigh has assessed the assumptions underlying the request for the survey and has produced the following conclusions:

(x) "that a scarcity of librarians for professional positions actually exists in the state and is of a size to call for an extension of training facilities;

(2) "that the growth of population in California will entail a growth of library service, but not so much an increase in pro- 
fessional library personnel as a reclassification of duties in libraries so as to substitute non-professional staff members for work now done by persons in professional positions;

(3) "that the lack of an excess of qualified applicants for entrance to the California library schools despite the excess of positions open to library school graduates indicates that the increase of the supply of library school graduates through larger library school enrollments is neither automatic nor sure ;

(4) "that the expansion of the facilities of instruction at the existing library schools is fully adequate for any probable increases in library school enrollments in the foreseeable future. Such an expansion would be more economical and more effective educationally than adding a fourth school to the present under-used educational facilities for professional librarians in California."

On the basis of these conclusions Dr. Leigh's report recommends as follows:

r. "That the addition of a third graduate library school at UCLA is unnecessary to accommodate present or prospective library school students in California, would be financially imprudent, and educationally unsound. The two existing graduate library schools are excellently located in the state's two major focal points of population and are fully capable, with modest additions to their staffs, budgets, and physical facilities, of accommodating any increase of student enrollments now in prospect. A third school would, almost surely, reduce the enrollment at the other two and would probably remain too small for maximum effectiveness as a center of graduate instruction and research in the library field. The recruiting of a third faculty with the required academic background combined with professional experience would be very difficult. It would be a risky and extravagant venture in the present circumstances.

2. "That the present effort should be directed rather to the full development of the two existing graduate library schools so that they will have the resources, staffs, and programs to make instruction easily available at the lowest cost possible to potential students, and to serve fully the varied needs of the libraries of the state for professional personnel, and for other expert help in dealing with library problems and processes.

3. "That if the University of Southern California does not feel that it can afford to expand and develop the library school now under its auspices to make it more equal to the task of fully serving the libraries of the
Southern region and the State, it consider the transfer of the School back to the auspices of a tax supported institution.

4. "That in order to promote the full development of the existing library school maintained by the University of California a standing advisory council to the School representing the library leadership of the state be constituted.

5. "That the Department of Librarianship at San Jose State College be further developed as the center of training for school librarians on the undergraduate level; and that the State Department of Education modify its regulations for authorizing such centers in line with the recent action of the American Library Association, turning over national accreditation of training institutions for school librarianship on the undergraduate level to the American Association of College Teachers of Education.

6. "That in consideration of the large numbers of librarians in the state revealed by the Survey to be holding positions classified as professional but who have had little or no professional training, and the much larger and growing number of those now holding nonprofessional jobs in libraries that require some instruction in library techniques and processes, attention be given by the State Library, the California Library Association, the library schools and the Extension Division of the University to the best means of providing intensive in-service or preservice training in library techniques avail. able to those who need it."

To this reviewer Dr. Leigh's report appears as a model of research reporting. His recommendations are presented with candor and straightforwardness in spite of the fact that they will not necessarily fulfill the hopes of those who authorized the Survey. His method of amassing the necessary data on California librarianship and of epitomizing professional opinion throughout the state indicates a singularly unprejudiced approach. It is obvious that in this report there has been no editing or wresting of the facts to support a pre-determined conclusion.

However, if there is a short-coming to be found with the report, it lies in its lack of exploration into the comparative ability of the state-supported institution versus the private one to provide superior facilities.

Whatever the course of action followed either in pursuing or ignoring the facts brought out in this report, its findings can well be taken to heart by the existing schools 
of librarianship. The report will also serve as a continuing source of well assembled and well presented data on California libraries nowhere else obtainable, since virtually all of the data presented was obtained by questionnaire, conference, or interview, and therefore is in no sense a synthesis of previous studies. -Harold L. Hamill, Los Angeles Public Library.

\section{University Librarianship}

Scholar's Workshop: Evolving Conceptions of Library Service. By Kenneth J. Brough. Introduction by Robert B. Downs. Urbana, University of Illinois Press, 1953. $\mathrm{xv}, 197$ p. $\$ 4.50$.

In Scholar's Workshop Kenneth J. Brough has assembled a considerable amount of historical evidence to show that during the past three-quarters of a century university librarianship has de-emphasized the traditional custodial function in favor of greater attention to "service."

After a rather brief treatment of the character of the library of the typical American colonial college, the author traces the development of the libraries of Harvard, Yale, Columbia, and Chicago, from roughly I 876 to the present, in terms of their position in the academic community, their clientele, the nature, extent and accessibility of their collections, their personal assistance to the reader, and the role of their librarians.

In the preface the author sets forth seven questions which the study proposes to answer:

What opinions have existed concerning the importance of the library in the university?

How have the functions of the university library been defined?

What differentiation of services has been considered desirable for the several classes of clientele of the library: professors, graduate students, undergraduates, and non-university public?

What thoughts have arisen about the nature and extent of the materials which the library should collect?

What ideas have emerged concerning the accessibility of books?

What conceptions have evolved with relation to the kind and amount of aid to be given readers?

How has the role of the librarian changed?
This is an interesting list of questions, and the answers of Mr. Brough provide us with a useful body of data. However, these are questions of fact: interpretation is secondary. The author asks only "what?" or "how?" rather than "why?" The plan of this undertaking, therefore, was limited from the start since causality, synthesis, and interpretation were not given prime importance. To be sure, one cannot properly criticize an author for accomplishing what he has set out to do, but one does have the right to question the objective. To write library history in terms of a changing pattern of library functions and objectives, and to relate those changes to the forces in our society which produced them would give to the evolution of the library as a social agency a new depth and meaning, but the study here reviewed does not provide the richness that it might have evinced.

Basically, the work is weakened by the failure to suggest that the changes that were taking place in university librarianship were paralleled by similar developments throughout the entire library field. What was happening in university librarianship was also happening, in much the same way, in public libraries as well. Yet the author does not make this explicit to the reader. Nor does he address himself to the problem of the causes that brought such changes about. These forces that lie beneath the surface should have been explored, and such exploration would have given the book a more significant depth.

Observations may also be made of the treatment of facts. An excessive amount of space is devoted to the attempt to establish the authenticity of the story told of J. L. Sibley, and incidentally of practically every other university librarian, concerning his excursion to retrieve from Agassiz the only two books missing from the Harvard library collection (p. 2, I6-17). The lengthy discussion (p. 132-134) of the New England Deposit Library makes no mention of Francis $X$. Doherty's definitive study of the subject ( $\mathrm{Li}$ brary Quarterly, v. I8, I949, p. 245-54), and only refers to the far more significant Midwest Inter-Library Center with a foot-note (p. 133). Since the study is limited to but four university libraries, many interesting movements toward increasing inter-library cooperation are not discussed.

The chapter on the role of the librarian fails to present with any degree of fullness 